\title{
Massive Multi-player Online Games and the Developing Political Economy of Cyberspace
}

\author{
Mike Kent
}

This article explores economics, production and wealth in massive multi-player online games. It examines how the unique text of each of these virtual worlds is the product of collaboration between the designers of the worlds and the players who participate in them. It then turns its focus to how this collaborative construction creates tension when the ownership of virtual property is contested, as these seemingly contained virtual economies interface with the global economy.

While these debates occur at the core of this virtual economy, at the periphery cheap labor from less-developed economies in the analogue world are being employed to 'play' these games in order to 'mine' virtual goods for resale to players from more wealthy countries. The efforts of the owners of these games, to curtail this extra-world trading, may have inadvertently driven the further development of this industry towards larger organizations rather than small traders, further cementing this new division of labor.

\section{Background}

In the late 1980s, multi-user dungeons (MUDs) such as LambdaMOO were text-based environments. These computer-mediated online spaces drew considerable academic interest.[1] The more recent online interactive worlds are considerably more complex, thanks to advances in computing power and bandwidth. Encompassing larger and more detailed worlds, they also enclose a much larger population of players. The first game in the new category of Massively Multi-player Online Role-playing Games (known initially by the acronym MMORPG and more recently as MMOG) was Ultima Online http://www.uo.com, which was launched over a decade ago in September 1997. While tracing their origins to the more humble MUD, MMOGs are very different environments. There are currently more than 200 different MMOG game worlds. EverQuest http:/ / everquest.station.sony.com/ was the early industry leader and is operated by Sony Online. At its peak EverQuest had nearly half a million players, although it now makes up just over one percent of the total market with less than 200,000 players (Woodcock 2008a). Currently, the most popular game in the genre, World of Warcraft http:/ /www.worldofwarcraft.com/, is operated by Blizzard Entertainment. In January 2008 this game passed a record 10 million active subscriptions (Blizzard 2008) and occupied more than 60 percent of the market (Woodcock 2008a).[2]

A distinct virtual world is rendered in each game, with different themes, activities and objectives for players. Normally players will purchase the game software, and then pay a monthly access fee. Within the game world players are projected as their avatars - digital representations of the characters they play - and gain virtual skills, equipment, and wealth. The value of this market is expected to reach US \$4.4 billion by 2010 (Burns 2006).[3] The games are of sufficient size and dimension that they have attracted the attention of security agencies concerned with terrorist training and communications (O'Harrow 2008). Software glitches have been used to aid the study of the spread of 
disease epidemics in the real world (Lofgren and Fefferman 2007).

While World of Warcraft is the current dominant game, there are a wide variety of genres and types of virtual worlds. Fantasy-type role playing games make up some 94 percent of all games followed by science-fiction-styled games at four percent (Woodcock 2008b). While many are competitive and story-driven there are others, such as Second Life http://secondlife.com/, that create less-guided virtual worlds. The number of people taking part in these games recently reached 16 million and is accelerating (Woodcock 2008c).

\section{Virtual Wealth}

This type of environment is significantly different from other spaces in the broader digital environment accessed through the Internet. Each game world is limited - it has a scarcity of resources and abilities. A player's avatar, and the virtual goods they create and own, share a constancy of production that mirrors off-screen goods. This contrasts with other 'normal' digital artefacts on the Internet which can be easily copied and distributed at minimal cost. While it might be possible to make a digital copy of a character's magic armor and sword from World of Warcraft, it would not be possible to do so in the context of the game - where the item's value is activated - without going through a similar process of production, whether it be fighting a virtual dragon, or time spent behind the bellows in the virtual smithy. Throughout history, the ideal of the best possible world has been one of abundance and ease, yet it is the constraints and limitations of the MMOG worlds that provide the challenge and appeal to players. As Edward Castronova (2001), Associate Professor of Telecommunications at Indiana University noted, 'people seem to prefer a world of constraints to a world without them'. Juul (2005) observes that these limitations present affordance as well as limitations, as quite simple rules can be used to create complex outcomes.[4]

This leads to a situation, in some games, where simple commodities that might otherwise have little value to players, take on a much higher economic significance, as time and effort must be spent to produce them. Similarly, in many worlds, characters or avatars that develop virtual skills and abilities over time become more valuable, by virtue of those attributes, than avatars that have only just been created. It takes time and effort to 'grow' them. This involves not just an expenditure of off-screen capital to pay for game subscriptions and Internet access, but an investment of the player's time, and effectively their labor, within these virtual worlds.

As well as goods, and avatars that require skill and dedication to build, MMOG worlds also contain commodities that are valuable due to their scarcity. There are some virtual items of which there are a limited number, either through the games design, or their production having been discontinued, or in the case of movable error messages in Ultima Online (a highly valuable 'rare' in the game), through programming errors. The most common manifestation of this type of resource, across the various MMOG worlds, is virtual land. Ultima Online, produced by Electronic Arts, had a land crisis as its virtual world Britannia became fully occupied, and prices for virtual land began to spiral. In response, the game's developers added a new continent to the world.

While these electronic fantasy worlds have some similarities to the off-screen economy, actions like this electronic version of continental discovery show that the analogy is far from perfect, although the parallel with European colonial expansion is compelling. The resultant land rush, as this new continent was opened to sale, meant that at one virtual location there were 13 player's avatars. Each player was trying to buy the land by continuously clicking their mouses on the spot while they waited for the 'option to purchase' in the game to be turned on. In the end only one player got to build their tower, when the option was activated (Dibbell 2003b). In this case it was time, effort, enterprise and luck that resulted in virtual wealth. Linden Lab the publishers of Second Life do not charge for a basic player a subscription, but rather make the majority of their revenue through the sale of land in their virtual world (Rappeport 2007).

\section{| Value Through Community}

Players generate not just their individual character's skills and possessions, they contribute to culture and community within the game. Taylor (2002) notes that this collective construction of the game environment is often overlooked. Humphreys (2005) divides the MMOG production in the virtual environment into 'tangible' 
and 'intangible' virtual assets. Tangible assets are those that can be attributed a value in relation to a specific entity. Examples are virtual gold coins, a magic sword, or an avatar's expertise as a carpenter. Intangible assets on the other hand are those that are generated by the communities and social environment that the game activates. Humphreys (2005) notes that these assets are created through both the paid labor of the game developers and the unpaid labor of the players as both combine to create the unique text of the particular virtual world. Tangible assets can potentially be transferred from one player to another, whereas intangible assets are the product of the community and the game and represent a kind of virtual public good.

These worlds are normally designed to be 'stand-alone' environments. As such, they have an internal consistency that rewards player's time and effort. The game-world borders, at first seeming closed, are actually quite porous. These games exist within space enabled through the Internet, access to which is a prerequisite to participation. The borders of these stand-alone environments expand beyond the direct control of world developers as players interact with each other through different applications online. A proportion of the 'intangible wealth', created both by the collective group of players and the world's developers, exists outside the game through discussion forums, at gamerelated websites and through other online venues. Given this, it is not surprising that activities in these out-of-virtualworld spaces have repercussions within the 'closed' space of the game.

In October 2000 a long time player of EverQuest had the account for his character 'Mystere' suddenly terminated while he was playing. After some investigation, the player found that this action had been taken due to the potentially offensive nature of some 'fan fiction' he had posted to the Elf Lore and EQ Vault online message boards (Burdage 2000). While neither of these sites was affiliated with Sony Online, the company said it had received complaints about the graphic nature of the story, which was a background to his EverQuest character, and took action, it said, in order to protect the reputation of the game (Taylor 2006).

In 2003 Peter Ludlow's Sims Online character 'Urizenus' was a celebrity eviction from that game. He had published his own web site, the Alphaville Herald, named after the main city in that virtual world. His offence was to expose some of the seedier sides to the game including virtual con men and virtual prostitution rings, and the fact that both were, according to the Herald, being carried out by underage players. Electronic Arts stated in a letter explaining their actions 'we feel it is necessary for the good of the game and its community' (Manjoo 2003).

While these reactions by the game owners can be understood in terms of their concerns about the off-screen image of the respective games, the reaction of the players, and the effect on the on-screen communities, illustrates the role of players in creating value through the generation of intangible capital. Players in EverQuest reacted to the eviction of Mystere by closing their own accounts, shutting down their fan sites on the Internet, and writing fan fiction of a more graphic nature than Mystere and then demanding that they too be banned from the game (Burdage 2000). Sony Online responded by having John Smedley, the CEO of the game, write an open letter officially apologizing to the players, and personally calling Mystere's player to invite him back into the game. He declined. Without the community created by the players, and the revenues from their subscriptions, the game's resources have no value. As Sara Grimes observed:

The collaborative and often symbiotic aspects of these shared production processes are presenting new challenges to legal concepts such as intellectual property and ownership. (2006)

More recently players have begun to protest on-mass within virtual worlds, particularly World of Warcraft. One of the first of these protests occurred in early 2005 when players created a group of avatars, mostly of naked gnomes, who congregated together in large enough numbers to crash the game's Argent Dawn server to protest against changes made to the game's warrior class. A virtual riot ensued including virtual riot police subduing the crowd (Castronova 2005a). These types of protests, within the parameters of the virtual world, are illustrative of the complex construction of the game's text. They are directed at both at the owners of that world and other players.

\section{When Economies Meet}

The 'tangible' wealth generated by creating goods and developing character abilities, and stored in real estate also manifests outside the closed games environments as it comes to represent off-screen value, rather than just being redeemable within the MMOG worlds for virtual currency. As Edward Castronova explains, 'The minute you hardwire constraints into a virtual world, an economy emerges, One-trillionth of a second later, that economy starts 
interacting with ours' (Dibbell 2003b).

In 2001, using the exchangeable value for virtual goods determined by eBay sales, Castronova estimated the GNP of Norrath - EverQuest's virtual world - was \$US135 million, which were it an analogue nation state would have placed it as the world's 77th richest economy (Krotoski 2004), roughly equivalent in terms of GNP per capita with Russia (Castronova 2001).[5] While no data is currently available for similar figures for World of Warcraft the game has a population, and thus potential market, more than twenty times the size of EverQuest in 2001.

Players are able to buy and sell goods, real estate, and avatars outside the confines of a virtual world through the Internet. Many of these sales were originally conducted through eBay http://www.ebay.com - the online auction site - through category 1654 which was reserved for goods from Internet games. In 2003 more than \$US 9 million was traded through this service (Ward 2004), although these sales excluded one of the largest of the virtual economies at the time. Sony had successfully lobbied e-Bay to not list goods from EverQuest as of April 2000 (Taylor 2002). In 2007 eBay banned the sale of all goods from MMOGs through its site[6] (Terdiman 2007). More recent estimates for the global trade in virtual goods are between US \$250 million and US \$800 million (Terdiman 2007).

The value of this tangible virtual wealth is founded on the intangible value created by the players and the developers of the various games. As Raphael Koster lead designer of Ultima Online, stated:

For every person you see selling an [Ultima Online] account on eBay... there are a bunch of people bidding, too. And they are bidding on intangibles. They are offering up their hard-won real money in exchange for invisible bits and bytes because they see the intangibles of $\mathrm{UO}$ as being something worth having. A tower for a sense of pride... I find it odd that people think this cheapens the whole thing. I think it validates it. (Farmer 2004).

Without the combination of the intangible value created by the community of players from Ultima Online, and the world produced by Electronic Arts which makes the game an enjoyable experience, a tower would have no value. It is only able to realize its off-screen value in it's on-screen context.

Within virtual worlds, players are divided in their attitude to this cross-border trade. This debate can be distilled into one of time against money. Players who have spent time in the various games generating virtual wealth resent others who are able to effectively buy their way into a powerful position in the game with off-screen and out-of-game wealth.

The argument follows that this disparity allows inequalities in the off-screen world to permeate the game world, and works against a game's leveling effect, where each new player enters the game with the same basic avatar. The counter to this argument is that this situation unfairly advantages those players who have time to spend in the game at the expense of those who have less capacity to play, but potentially a higher level of disposable income. Vendors of virtual goods refer to this as a need for 'power levelling'. Interestingly, both arguments are premised in a desire for all players in the game environment to be equal. While there is a degree of hostility to 'power levelling' or eBaying as the practice is know, there is much less player disquiet about the practice of 'twinking' where a new player is 'gifted' equipment and other resources from an existing character (Jakobsson \& Taylor 2003), perhaps due to the transaction occurring entirely within the borders of the virtual world.

Different games have different attitudes towards extra-world commerce. Some, such as Linden Lab's Second Life, encourage the growth of the world beyond its virtual borders and are happy with free trade across their virtual territory. Philip Rosedal, CEO of Linden Lab explained 'It's great. It's hyper-liquid. When you reduce trade borders you get faster development.' (Terdiman 2004a).

Others however are more protectionist and actively work to block this type of trade. EverQuest attempts to keep the game within closed borders. The Sony end-user licence agreement (EULA), which the players must agree to at the start of each online session, states: ...You may not buy, sell or auction (or host or facilitate the ability to allow others to buy, sell or auction) any Game characters, items, coin or copyrighted material. (Farmer 2004)

Chris Kramer, Sony Online Director of Public Relations emphasized:

The official line is that the selling of characters, items or equipment in EverQuest goes against our end user agreement. It's currently not something the company supports and causes us more customer service and game-balancing problems than probably anything else that happens within the game. (Terdiman 2004b)

For the owners of many virtual worlds, the time it takes each character to develop both skills and equipment is central to the game's economic model. Each player must invest time to develop their character (and be rewarded for that time with character improvement), and thus provide revenue from subscriptions. However, as Taylor (2002) 
notes, the fact that games provide mechanisms for trading and sales of items within their 'closed' worlds both facilitates the 'cross-border' trading and makes the magnitude of the offense ambiguous.

\section{Who Owns a Virtual World?}

In 2002, Dark Age of Camelot http://www.darkageofcamelot.com/, owned by Mythic Entertainment, closed the accounts of Black Snow Interactive (BSI) for selling large numbers of high-level or powerful avatars in their game world and were subsequently taken to court for unfair business practices in a case that remains unresolved (Castronova 2005b). The same BSI was itself unsuccessfully sued by Anarchy Online www.anarchy-online.com for 'grinding' too many accounts (Krotoski 2004). Grinding is an industry phrase for taking basic, entry-level avatars and playing them until they become more powerful, and then selling them to new players. This process engages an economic constancy of production. Each unit produced requires just as much time and resources as the unit before, and the unit after. Many of the other tangible goods in the game share a similar production pattern, the same amount of virtual and off-screen resources are needed to make each virtual product. As Jordan (2005) notes 'within MMPOGs there is only one factor that fundamentally determined production value: time'. Jordan observes that this process starts to intermingle notions of work and leisure when done by players as part of their participation in the game (2005). When this practice is conducted in an organized and professional way it generates a fordist mode of production in an otherwise post-fordist casual economy. For those involved, it crosses the line between these environments marking spaces where the players are engaged in recreational activity, to one where they are involved in virtual labor.

The role of the multiple actors, both players and developers, involved in the creation of the 'text' of each of these games has generated considerable debate about the ownership of this type of virtual public space. Taylor (2004) argues that this is, in part, due to the evolution of the game worlds from the essentially public 'not for profit' spaces of the text based MUDs to the commercialized industry of MMOGs. A number of writers have postulated there may be a need for a new construction of intellectual property and copyright to be developed for these environments. [7] Although, as Castronova (2003) notes, the extensive use of EULAs in the industry currently heavily favors the owners and developers of the games.

There is much debate over who owns the fruits of virtual labor in these virtual worlds. As Grimes (2006) notes 'Nowhere have the tensions between user and corporate interests more clearly manifested than within the realm of online gaming.' Are the players able to do as they wish with the product of their labor, including exporting it through the off-screen world, or is this virtual produce still subject to the copyright of the game's owners, and still their (virtual) possession? Are the goods owned by the company that produces the game, the virtual owners of the means of production, or the players that cause the production within the game, the virtual workers, who thus should own the produce of their virtual labor? Within this context, the debates about how the game is 'played' take on a classic Marxist positioning. Lee Cadwell, Director of Sales at Black Snow Interactive, stated, What it comes down to, is, does a MMORPG player have rights to his time, or does Mythic own that player's time?' (Slagle 2002).

The monetary importance of this question is evident by the fact that the trade in virtual goods generate between US $\$ 250$ million and US $\$ 800$ million in a year (Terdiman 2007). While it would seem that the law in most cases would support game owners' copyright, and enforcement of the end-user licence agreements by the developers of the games over the players, courts in China have notably come down in favor of the players, ruling that it is they who own the fruits of their labor, perhaps reflecting the state's communist ideology (Russell 2004).

\section{Trading Virtual Goods}

Julian Dibbell (2003a) describes the MMOG economy:

It's a whole new species of economy - perhaps the only really new economy that, when all has boomed and crashed, the Internet has yet given rise to. And how poetic is that? For years, the world's economy has drifted further and further from the solid ground of the tangible: Industry has given way to post-industry, the selling of products has given way to the selling of brands, gold bricks in steel vaults have given way to financial derivatives half a dozen levels of abstraction removed from 
physical reality. This was all supposed to culminate in what's been called the virtual economy - a realm of atomless digital products traded in frictionless digital environments for paperless digital cash. And so it has. But who would have guessed that this culmination would so literally consist of the buying and selling of castles in the air?

The virtual borders of these online worlds are made porous through a number of mechanisms. Originally eBay had provided one of the main marketplaces for trade in virtual goods. This in turn was facilitated by fund transfer and trust enabling services such as PayPal http://www.paypal.com. These services were further aided by the use of email, instant messaging, the World Wide Web and telephones to enable different customers and vendors to meet in the virtual marketplace.

While some trading, both within and outside of the various MMOG environments, is done between individuals, there is also a place in this market for traders or merchants to buy and sell goods and act to facilitate transactions between buyers and sellers. The tower from Ultima Online's Britannia was sold along with the rest of the user's account for US $\$ 500$ after the player was unable to find work off-screen and needed to realize some of the value of their on-screen assets. The tower and land, along with belongings and characters, was put up for auction on eBay, but before the auction took place, the player was contacted by a MMOG trader, Bob Kiblinger, who broke up the various virtual assets for sale on his web site www.12treasures.com (Dibbell 2003b).

While these traders were originally individuals, or small teams, the industry has increasingly moved towards larger organizations. One of the first of these was Black Snow Interactive. This was one of the first major players in the virtual goods industry, and provoked the first set of litigation in this area, both initiated by BSI against Mythic Entertainment, and also directed towards the company from Anarchy Online. However by June 2002, the company and its directors had disappeared, without paying their legal bills (amongst many of the company's other suppliers), and the case against Mythic was dropped (Dibbell 2003c).

Internet Gaming Entertainment (IGE) http:/ / www.ige.com, founded in 2001, became one of the largest players in the tertiary virtual-goods industry. With its corporate headquarters in the United States at New York and Miami Beach, it has an office in Hong Kong processing orders for virtual goods (Terdiman 2004b). While IGE sells a wide variety of virtual goods, there are other companies that became more specialized.

\section{Banking Virtual Currency}

Gaming Open Markets (GOM) provided a currency exchange between different MMOG worlds, as well as the U.S. dollar. This service rendered the borders of these virtual worlds porous to each other without having to pass through the off-screen world for currency exchange. The company tracked the values of different virtual currencies, which fluctuate according to their supply and demand.[8]

This company's operations illustrated the complexity of trading across the many borders between virtual worlds. To bank money with GOM, a player first had to go to their Web site and open an account. They could then book a deposit, when an avatar of one of the company's agents would arrange a time, and virtual location to meet and transfer the currency. The agent was an avatar of a real person rather than a computer simulation or bot, as GOM did not have access to the computers running the various virtual worlds in which they operated. The player was told via e-mail of a password that the agent would use, so that they knew that the agent is a legitimate employee of Gaming Open Markets and that they are not giving their currency deposit to a fraud. The player then replied with their own password to verify their identity to the agent. This currency, once banked, could then be traded through the company's Web site. If the player wished to buy virtual currency for off-screen cash, then they made a deposit to GOM using PayPal. For GOM, the danger was that the company running the MMOG in question will become displeased with their operation, and locate and delete one of the avatars that hold their virtual cash reserves. However, while the company running each game did, as illustrated above for Mystere and Peter Ludlow, have this sovereignty over life and death of the avatars within its various worlds, they are not omnipresent. Detecting the actual agent could prove problematic. Eventually the difficulties in negotiating the borders of different virtual worlds removed GOM from the marketplace in late 2005 (Combs 2005).

The type of virtual meeting described above with GOM is a standard part of doing business across the borders of MMOG worlds. When the tower and land in Britannia was sold by L2treasures the new owner was delivered the keys by an avatar named Blossom. This turned out to not even be Bob Kiblinger, but his cousin Eugene, who he paid US \$10 an hour to make his various deliveries and pickups in the virtual world (Dibbell 2003b). Blossom/Eugene 
fulfilled a customer service role within in this industry. While requiring a certain level of literacy in the operation, employing agents such as this allows for the more efficient use of those with the stronger literacy and capital required to value, purchase and sell virtual goods, who then can concentrate on this revenue generation.

While Gaming Open Markets played an important role in developing trade in virtual currencies and withdrew from the market only after allowing their clients to withdraw their deposits other virtual bankers have been less proprietous. Linden Lab banned all banks without an appropriate government registration from trading in Second Life following the collapse on Ginko Financial in 2008, which caused losses equivalent to \$US 700000 in Second Life currency (Miller 2008). A number of similar operations in that world were offering extremely high rates of return in many cases operating as thinly disguised Ponzi schemes (Miller 2008).

While this type of online fraud is not uncommon on the Internet it can become more ambiguous in the context of different virtual worlds. Another famous banking scandal occurred in the science fiction themed Eve Online http:/ / www.eve-online.com in 2006. In this case a player 'Calley' was behind what became known as the EIB scandal when they made off with all the deposits from the Eve Intergalactic Bank of which they were the proprietor. While in different circumstances this might be seen as a criminal act, within the context of the game it was seen as not breaking any of the rules. The game while not necessarily encouraging this type of behavior amongst its players does not specifically outlaw it as players take part in the game world, as it was noted at the time no actual money was stolen. However, the 790 billion Inter Stellar Kredits (ISK) of the game's currency that was involved could fetch as much as US \$170 000 dollars in the market for virtual goods (Pollack 2006), making it potentially a very lucrative operation.

\section{The Virtual Economy Meets the Global Economy}

There is more activity in the virtual digital economy than this initial overview of the MMOG environment provides. Ken Selden the Chief Economist at Internet Gaming Entertainment noted 'There's a relationship between real-life economics and a virtual economy. I happen to believe that these virtual economies are very real, serious economies' (Terdiman 2004b).

This new digital political economy lays down an added layer of disadvantage on that already present off-screen. The constancy of production of goods in virtual games makes them more analogous to off-screen goods than other digitized goods and services that can be easily copied and transported. It is of little surprise then to find that the production and design of these goods comes to mirror patterns found in the off-screen economy. The production of goods that require relatively complex skills remains at the core, and to this end the companies trading in virtual goods will purchase rare and expensive virtual items from active players based in the various game worlds. Production that requires relatively unskilled labor can be conducted more efficiently through the exploitation of cheap labor in the periphery.

Black Snow Interactive were the first company to act on this understanding that a form of production that requires time, unskilled labor, and can be located anywhere with access to the Internet, would be most efficiently done where hourly wages were low, and then this produce could be sold where money was relatively abundant. [9] While the company was claiming in its lawsuit against Mythic Entertainment that it was defending the interests of players in The Dark Age of Camelot, [10] it had in fact, rather than merely acting as a trader, also set up its own production facility in Tijuana, Mexico.

BSI had set up a facility with a high bandwidth Internet connection and eight computers. It was running three shifts to keep the operation going 24 hours a day, seven days a week, using relatively cheap unskilled Mexican labor to grind characters in the game for resale to American players. This was in the words of Julian Dibbell (2003b) the world's 'first virtual sweatshop', where the virtual and American economies interfaced. In the MMOG world with its constancy of virtual production the on-screen and off-screen periphery and core conflate.

While Black Snow Interactive ceased operation, Internet Gaming Entertainment seems to be following a similar business model. The company needs to send it's avatars into a game where it is trading and travel in the virtual world, this 'travel' however can be based anywhere. The company has thus, already located their distribution operation in Hong Kong, which also runs 24/7. The company has described their suppliers as a group of more than 100 hardcore players who sell the company their excess currency, weapons and other goods (Terdiman 2004b). However, many of these 'hard core players' are subcontractors operating in Mainland China running operations similar to that at 'Tijuana, although this time on a much more expansive scale (Dibbell 2003a). Large 'farms' initially mostly based in 
China, but operating wherever wages are low, house large numbers of computers running 'bots', programs that run the various money making activities in each game and overseen by low wage virtual farmers. These workers in China earn around 56 cents an hour (Lee 2005). In this context China's laws on the ownership of virtual labor in MMOGs, rather than protecting the rights of a virtual proletariat, may instead be a facilitator for this kind of operation.

A study of World of Warcraft by Ducheneaut, Yee, Nickell and Moore in 2006 identified 245 avatars that were online more than 15 hours a day over a two week period (putting them in the top 0.01 percent of avatar activity) in the five servers they monitored, and thus likely to be being played in shifts by more than one player in a professional context. This would extrapolate to approximately 5243 of these high-use gold farming avatars on U.S. servers in that game alone. Interestingly the rogue character class was chosen for these characters by the majority of these farming operations (Ducheneaut et al 2006).

While gold farming generally occurs in violation of different games end-user licence agreements the same principles have also been applied more overtly. In November of 2006 Anshe Chung, of Anshe Chung Studios http://www.anshechung.com in Second Life, issued a press release announcing that she had amassed a real-estate portfolio and other wealth within Second Life that was worth one million U.S. dollars and declared herself the world's first Second Life millionaire (Anshe Chung 2006). Anshe Chung is the Second Life avatar of Guntram and Ailin Graef. Their company develops virtual property in Second Life. Their business model is not dissimilar the gold farming. They take orders for virtual buildings and other virtual artefacts from players and companies based in wealthy developed countries (the couple themselves live in Germany), and then have these products produced by relatively inexpensive labor in China. As with gold farming, Second Life is designed so that players can build things in the virtual world with limited training, allowing staff to be easily employed requiring no specialist skills. This process is facilitated by Second Life policies that allow players to own the copyright on anything they create within the game world and encouraging economic activity across its own borders.

IGE's operations in relation to the MMOG economies stretch from the very core of the digital political economy to its periphery. At the core, the various game's owners and assorted traders in virtual goods fight for control of the legal and moral ownership of virtual property, one that will support their understanding of how the economic system should operate. In this struggle it is of little surprise to see a division of Sony, a member of the Recording Industry Association of America and Motion Picture Association of America, central in the fight for ownership and enforcement of game owner's copyright. As Taylor (2002) notes the company takes the EverQuest slogan 'You're in Our World Now' quite literally. While Sony Online lead the way in shutting down eBay trades in virtual goods, this may have ultimately helped spawn and support organizations like IGE which will have far greater influence, both on the game and in their ability to influence these contests of ownership, than a few individual traders might have. Although the exemption of Second Life from these political manoevrings does not seem to have seriously impinges Amy Chung's lucrative role as an intermediary between virtual production and consumption.

Also close to the core of the virtual political economy are those smaller traders such as L2treasures who are able to exploit their high level of literacy in this area to make a profit. Further from the core, but still a long way from the edges of periphery, are those employed at the intermediate levels of this trade, at the digital semi-periphery - including the IGE employees in the Hong Kong office engaged in processing customer's orders and the delivery avatar for L2treasures. Both are examples of those employed in virtual customer service.

This core and periphery is then laid out on top of existing off-screen economic relations. Cheap labor in Mainland China is exploited and serviced by companies based in Hong Kong. This labor is then in turn exploited as its production is used to service those at the economic core in North America and Western Europe. The efforts of the owners of these virtual worlds to limit trading in their respective virtual goods may have had the effect of further cementing the role of larger intermediary companies such as IGE as other avenues of communications between buyers and sellers such as eBay are closed. Terdiman (2007) quotes Dibbell:

eBay's move is "a boon for sites like IGE," said Julian Dibbell, author of Play Money: or How I Quit My Day Job and Struck it Rich in Virtual Loot Farming. "They're going to have the field pretty much to themselves."

While maintaining existing global inequalities, there are some aspects of the new virtual sweatshops that are an improvement on the more traditional analogue version. Gold farmers in World of Warcraft are unlikely to have to endure the toxic fumes of the sports shoe factories that preceded them. Similarly Raiter and Warner (2005) note that while staff in these factories are not highly paid they are better renumerated than for equivalent work in agriculture. MMOGs are also rapidly growing in their own right in new markets such as China, where the industry grew 60 
percent in 2007 and is expected to exceed revenues of US \$3 billion by 2010 (Dring 2008).

\section{Conclusion}

The players in the game debate whether it is they - the workers - who own the fruit of their labor, and thus can take the rewards for this labor outside the game, or bring their external resources into virtual worlds, or if it is the companies running the worlds - the owners of the means of production - who own what is produced in those worlds. It is then left to academics to grapple with the question of governance and construction of the value within these privately owned communal spaces. While in the periphery, both digital and off-screen, and beyond their ability to engage from the digital core, there is exploitation of labor in the grinding of the virtual goods at the center of these debates.

In an echo of the mills of Manchester that used to drive the production of cotton in the colonies of the British Empire, so too the virtual sweatshops at the periphery of the virtual economy are driven by production at the core. The intangible capital created by both players and game designers in the production of the complex texts of MMOGs online, provides the foundation for the value of the tangible assets cheaply mass-produced at the analogue periphery. MMOGs do not require a high level of skills and literacy to play. This makes them perfect vehicles for the extraction of value by unskilled, low paid workers who inhabit both the off-screen, and digital periphery. As with other areas of the digital periphery, these workers cannot be seen, indeed are not spoken of, in the debates at the core of the virtual economy.

\section{Endnotes}

1. See Dibbell (1998), Kendall (1996), Reid (1996), Turkle (1996), and Kolo and Baur (2004).

2. World of Warcraft has 2 million subscribers in Europe, 2.5 million in North America and 5.5 million in Asia and is currently played in seven different languages (Blizzard 2008).

3. Although other predictions are more bullish with some expecting the market to grow to US $\$ 3$ billion in China alone in that time period (Dring 2008).

4. Juul uses the game of chess as a compelling example of this phenomenon.

5. For a more detailed analysis of in game income Jordan (2006) provides an analysis and comparison for Castronova's findings that focuses on The Dark Ages of
Camelot.

6. The virtual world of Second Life was explicitly exempted from this ban by eBay.

7. See Brudage (2000), Castronova (2003), Farmer, (2004), Grimes (2006), Humphreys (2005) Jakobsson \& Taylor (2003), Taylor (2006) and Taylor (2002).

8. MMOG worlds are notorious for periods of hyperinflation when software bugs are discovered that facilitate rapid production of virtual currency.

9. Or at least were the first company to have been exposed in the process of engaging in this process.

10. Of whom there were approximately 250,000 at the time.

\section{References}

Anshe Chung Studios. 2006. "Anshe Chung Becomes Worlds First Virtual Millionaire”, Press Release. November 26th. Accessed March 24, 2008 http://www.anshechung.com/include/press/ press_release $251106 . \mathrm{html})$.
Blizzard Entertainment. 2008. "World of Warcraft Reaches 10 Million Players", Press Release. January 22nd. Accessed March 8, 2008 http://www.blizzard.com/us/press/080122.html) 
Brudage, Sandy. 2000. “EverQuest Strips the Dark from 'Dark Elf”, Games.Com October. Accessed March 9, 2008 (http:// www.gamegirladvance.com/mmog/archives/2002/10/21/ stripping_the_dark_from_dark_elf_in_eq.html).

Burns, Enid. 2006. "Online Games Market to Hit 4.4 Billion by 2010", The ClickZ Network August 30th. Accessed March 22, 2008 (http://www.clickz.com/showPage. html?page=3623306).

Castronova, Edward. 2005a. "Synthetic Statehood and the Right to Assemble”, Tera Nova February1st. Accessed March 24, 2008 (http://terranova.blogs.com/terra_nova/2005/02/ the_right_to_as.html).

-----. 2005b. Synthetic Worlds: The Business and Culture of Online Worlds. London: The University of Chicago Press.

----.. 2003. “On Virtual Economies”, Games Studies December, Volume 3, Issue 2. Accessed March 11, 2008 (http://www. gamestudies.org/0302/castronova/).

-.---. 2001. "Virtual Worlds: A First-Hand Account of Market and Society on the Cyberian Frontier", CESifo Working Paper No. 618. December. Accessed March 22, 2008. http://papers. ssrn.com/sol3/papers.cfm?abstract_id=294828).

Coombs, Nate. 2005. “RIP: Gaming Open Markets?”, Terra Nova September 28th. Accessed March 24, 2008 http://terranova. blogs.com/terra_nova/2005/09/rip_gaming_open.html).

Dibbell, Julian. 2003a. "Play Money Meet Big Money", Juliandibbell.com November 18th. Accessed March 24, 2008 http://www.juliandibbell.com/playmoney/2003_11_01_ playmoney_archive.html).

-----.2003b. “The Unreal Estate Boom”, Wired Magazine January. Accessed March 9, 2008http://www.wired.com/wired/ archive/11.01/gaming.html).

-----.2003c. "Serfing The Web: Black Snow Interactive and the World's First Virtual Sweat Shop", Wired Magazine January. Accessed March 24, 2008 http://www.juliandibbell.com/texts/ blacksnow.html).

-----.1998. My Tiny Life: Crime and Passion in a Virtual World. New York: Henry Holt.

Dring, Christopher. 2008. "China: Online Games Sees Massive Growth", MCVUK.Com March 20th. Accessed March 23, 2008 https://www.mcvuk.com/news/29965/ CHINA-Online-gaming-sees-massive-growth).

Ducheneaut, Nicholas. Nick Yee, Eric Nickell, and Robert J. Moore. 2006. "Building a MMO With Mass Appeal: A Look at Gameplay in World of Warcraft.” Games and Culture. October, Volume 1, Number 4:281-317. Accessed March 11, 2008 (http://gac.sagepub.com/cgi/reprint/1/4/281).

Farmer, F. Randall. 2004. "KidTrade: A Design for an eBay-resistant Virtual Economy”, Position Paper presented at State of Play II Reloaded, New York: 'Virtual Property/Real World Markets: Making a Living in a Virtual World' panel. October. Accessed March 11, 2008 http://www.fudco.com/habitat/archives/ KidTrade.pdf).
Grimes, Sara. 2006. “Online Multiplayer Games: A Virtual Space for Intellectual Property Debates?”, New Media and Society Volume 8, Number 6:969-990. Accessed March 11, 2008 http://nms.sagepub.com/cgi/reprint/8/6/969).

Humphreys, Sal. 2005. "Productive Players: Online Computer Games' Challenge to Conventional Media Forms." Communication and Critical Cultural Studies Volume 2, Number 1:36-50.

Jakobsson, Mikael. and T. L. Taylor. 2003. "The Sopranos Meets EverQuest: Social Networking in Massively Multiplayer Online Games", Ezine August, Volume 17, Issue 18. Accessed March 9, 2008 http://www.mediacritica.net/courses/711/ jakobsson.pdf).

Jordan, T.R. 2005. "Virtual Economics and Twenty-First Century Leisure”, Fast Capitalism 1.2. Accessed April 6, 2008 (http://www.fastcapitalism.com/).

Juul, Jesper. 2005. Half Real: Video Games Between Real Rules and Fictional Worlds. Cambridge Massachusetts: The MIT Press.

Kendall, Lori. 1996. "MUDder? I Hardly Know Er! Adventures of a Feminist MUDder". In Wired_Women: Gender and New Realities in Cyberspace, edited by Lynn Cherney and Elizabeth R. Weise. Seattle: Seal Press.

Kolo, Castulus and Timo Baur. 2004. "Living a Virtual Life: Social Dynamics of Online Gaming”, Games Studies November, Volume 4, Issue 1.

Krotoksi, Aleks. 2004. "Real Profits from Play Money", The Guardian April 15th. Accessed March 19, 2008 (http://www. guardian.co.uk/technology/2004/apr/15/media.newmedia).

Lee, James. 2005. "Wage Slaves", Computer Gaming World July 5th. Accessed March 11, 2008 (http://www.1up.com/do/ feature?cId=3141815).

Lofgren, Eric T. and Nina H. Fefferman. 2007. “The Untapped Potential of Virtual Game Worlds to Shed Light on Real World Epidemics." The Lancet September,Volume 7, Issue 9:625-629. Accessed March 9, 2008 http://terranova.blogs. com/s14733099077021283.pdf).

Manjoo, Farhad. 2003. "Raking Muck in 'The Sims Online." Salon.Com December 12th. Accessed March 9, 2008 http://www.salon.com/tech/feature/2003/12/12/ sims_online_newspaper/index_np.html).

Miller, Nick. 2008. "Virtual World Cracks Down on Cowboy Banks”, The Age January10th. Accessed March 8, 2008 http:// www.theage.com.au/articles/2008/01/10/1199554807218. html).

O'Harrow, Robert. 2008. "'Spies' Battleground Turns Virtual”, Washington Post February 6th. Accessed March http://www. washingtonpost.com/wp-dyn/content/article/2008/02/05/ AR2008020503144.html).

Pollack, Peter. 2006. “Online 'Banker' Runs Off with Cash, Avatars Cry Foul>” Ars Technica August 28th. Accessed March 24, 2008 http://arstechnica.com/news.ars/ post/20060828-7605.html). 
Rappeport, Alan. 2007. “Second Life's John Zdanowski”, CFO Magazine October 1st. Accessed April 16, 2008 http://www. cfo.com/article.cfm/9858165).

Reid, Elizabeth. 1996. "Communication and Community on Internet Relay Chat: Constructing Communities.” In High Noon on the Electronic Frontier, edited by Peter Ludlow. Cambridge MA: MIT Press.

Raiter, Mike and Dorothy E. Warner. 2005. "Social Context in Massively-Multiplayer Online Games (MMOGs): Ethical Questions in Shared Space", International Review of Information Ethics Volume 4 (12/2005):46-52. Accessed March 22, 2008 http://www.i-r-i-e.net/inhalt/004/WarnerRaiter.pdf).

Russell, Mark. 2004. "Grey Market. New Industry: Scavengers Collect Virtual Booty in Online Games and Sell it for Real Cash." Newsweek International, October 11th. Accessed March 26, 2008 http://www.newsweek.com/id/55156?tid=relatedcl).

Slagle, M. 2002. "Online Games Pay Real Cash for Virtual Objects”, AP Online. March 25th.

Taylor, T.L. 2006. Play Between Worlds: Exploring Online Game Culture London: The MIT Press.

-----. 2004. "The Social Design of Virtual Worlds: Constructing the User and Community Through Code", in Internet Research Annual, Volume 1: Selected Papers from the Association of Internet Researchers Conferences 2000-2002, edited by M. Consalvo, N. Baym, J. Hunsinger, K. Jensen, J. Logie, M. Murero, and L. Shade. New York: Peter Lang.

2002. "Whose Game Is This Anyway?: Negotiating Corporate Ownership in a Virtual World." In Computer Games and Digital Cultures Conference Proceedings, edited by Frans. Mayra. Tampere: Tampere University Press, 2002.
-.---. 2007. "eBay Bans Auctions of Virtual Goods." CNET News.com January 29th. Accessed March 22, 2008 http://www.news.com/eBay-bans-auctions-of-virtualgoods/2100-1043_3-6154372.html).

------. 2004a. "Virtual Cash Breeds Real Greed.” Wired Magazine January 23rd. Accessed March 11, 2008 (http://www.wired. com/gaming/gamingreviews/news/2004/01/61999)

-..-.. 2004b. "When Play Money Becomes Real." Wired Magazine April 7th. Accessed March 11, 2008 http://www. wired.com/news/games/0,2101,62929,00.html).

Turkle, Sherry. 1996. Life on the Screen: Identity in the Age of the Internet. New York: Simon and Schuster.

Ward, Mark. 2004. "Virtual Cash Goes Live." BBC News January 7th. Accessed March 10, 2008 http://news.bbc.co.uk/2/hi/ technology/3368633.stm).

Woodcock, Bruce Sterling. 2008a. "MMOG Subscriptions Market Share - February 2008.” MMOGCHART.COM Accessed March 22, 2008 http://www.mmogchart.com/).

-----. 2008b. "MMOG Subscriptions Market Share by Genre February 2008." MMOGCHART.COM Accessed March 22, 2008 http://www.mmogchart.com/).

-...-2008c. "Total MMOG Active Subscriptions." MMOGCHART.COM Accessed March 22, 2008 (http:// www.mmogchart.com/). 
